\title{
The role of nuts consumption in the primary and secondary prevention of type 2 diabetes
}

\section{ABSTRACT}

Type 2 diabetes (DMT2) constitutes approximately $90 \%$ of all diabetes cases worldwide and its main feature is chronic hyperglycaemia, which may lead to endothelium dysfunction, atherosclerosis, hypertension, microangiopathy, nephropathy, retinopathy and strokes. Therapy of patients with type 2 diabetes, despite the control of glycaemia, should encompass surveillance of lipid profile, blood pressure and body mass as factors increasing the risk of cardiovascular diseases. The aim of this study was to indicate the association of the consumption of nuts with lower risk of DMT2 and its complication prevention. It was established that the nuts have a positive impact on postprandial glycaemia decrease, insulin sensitivity improvement, ideal body mass maintenance (or its reduction among overweight people) and blood pressure control. As has been shown, implementation of nuts into DMT2 patients' diet may reinforce the efficacy of the treatment outcomes. (Clin Diabetol 2017; 6, 1: 26-33)

Key words: diabetes mellitus type 2, diet, nuts, hyperglycaemia, insulin resistance, hypertension, overweight
Address for correspondence: lic. Agata Klementyna Stróżyk Warszawski Uniwersytet Medyczny Zakład Żywienia Człowieka

ul. Erazma Ciołka 27, 01-445 Warszawa

Phone: 516435266

e-mail: ag.strozyk@gmail.com.

Translation: GROY Translations

Clinical Diabetology 2017, 6, 1, 26-33

DOI: 10.5603/DK.2017.0005

Received: 08.10.2016

Accepted: 15.03.2017

\section{Introduction}

According to the estimation of WHO (World Health Organisation), type 2 diabetes is to be the seventh on the list of the causes of death by 2030 [1]. In accordance with the data provided by IDF (International Diabetes Federation,) in $2015415 \mathrm{mln}$ people were diagnosed with diabetes and it is expected that by 2040 this number will reach $642 \mathrm{mln}$ [2].

The causes of the increasing prevalence of the disease include excessive body weight, unhealthy diet, lack of physical activity, hypertension, insufficient intakes for energy and nutrients during pregnancy as well as smoking [1-4]. The higher incidence of the disease was observed in people of lower income in highly developed countries, whereas, an opposite tendency was noticeable in countries with low Gross National Income (GNI) [1]. It was also found that regular, moderate physical activity as well as healthy balanced diet may could fully prevent or slow the onset of type 2 diabetes in high-risk patients [1-5]. It is therefore appropriate for to be of interdisciplinary nature, and the feasible dietary approach procedure should play a significant role in the primary and secondary prevention of type 2 diabetes [4, 5].

Both for people belonging to the risk group and the ones diagnosed with type 2 diabetes, the recommended diet product are nuts. They were found to be a major source of protein, lipoids and fibre (3.7-12.5 $\mathrm{g} / 100 \mathrm{~g}$ ). This is especially important including the recommendations on the standard intake of fibre in diabetes-diagnosed patients $(25-40 \mathrm{~g} / \mathrm{d}$ ) [6]. In the absence or the low proportions of sodium, they demonstrate the significant quantity of calcium, magnesium and potassium. In addition, they contain tocopherol and selenium, which show strong antioxidant properties. It must be noted that this review took into con- 
Table 1. Energy and nutritional value of selected species of nuts (own work based on [6])

\begin{tabular}{lcccccccccc}
\hline $\begin{array}{l}\text { Species } \\
\text { of nut }\end{array}$ & $\begin{array}{c}\text { Energy } \\
{[\mathrm{kcal}]}\end{array}$ & $\begin{array}{c}\text { Protein } \\
{[\mathbf{g}]}\end{array}$ & $\begin{array}{c}\text { Arginine } \\
{[\mathbf{g}]}\end{array}$ & $\begin{array}{c}\text { Total } \\
\text { carbohydrates } \\
{[\mathbf{g}]}\end{array}$ & $\begin{array}{c}\text { Fibre } \\
{[\mathbf{g}]}\end{array}$ & $\begin{array}{c}\text { Sucrose } \\
{[\mathbf{g}]}\end{array}$ & $\begin{array}{c}\text { Total } \\
\text { lipids [g] }\end{array}$ & $\begin{array}{c}\text { SFA [g] } \\
\text { MUFA } \\
{[\mathbf{g}]}\end{array}$ & $\begin{array}{c}\text { PUFA } \\
{[\mathbf{g}]}\end{array}$ \\
\hline Macadamia & 718 & 7.91 & 1.4 & 13.82 & 8.6 & 4.43 & 75.77 & 12.061 & 58.877 & 1.502 \\
Pecan & 691 & 9.17 & 1.2 & 13.86 & 9.6 & 3.97 & 71.97 & 6.18 & 40.801 & 21.614 \\
Pine nut & 673 & 13.69 & 2.4 & 13.08 & 3.7 & 3.45 & 68.37 & 4.899 & 18.764 & 34.071 \\
Brazil nut & 659 & 14.32 & 2.14 & 11.74 & 7.5 & 2.33 & 67.1 & 16.134 & 23.879 & 24.399 \\
Walnut & 654 & 15.23 & 2.28 & 13.71 & 6.7 & 2.43 & 65.21 & 6.126 & 8.933 & 47.174 \\
Hazelnut & 628 & 14.95 & 2.21 & 16.7 & 9.7 & 4.2 & 60.75 & 4.464 & 45.652 & 7.920 \\
Almond & 579 & 21.15 & 2.46 & 21.55 & 12.5 & 3.95 & 49.93 & 3.802 & 31.551 & 12.329 \\
Pistachio & 562 & 20.27 & 2.13 & 27.51 & 10.3 & 6.87 & 45.39 & 5.556 & 23.820 & 13.744 \\
Cashew & 553 & 18.22 & 2.12 & 30.19 & 3.3 & 5.81 & 43.85 & 7.783 & 23.797 & 7.845 \\
Groundnuts & 567 & 25.8 & 3.08 & 16.13 & 8.5 & 4.72 & 49.24 & 6.279 & 24.426 & 15.558 \\
\hline
\end{tabular}

All values are expressed per $100 \mathrm{~g}$ of dry product

SFA — saturated fatty acids; MUFA — monounstaurated fatty acids; PUFA — polyunsaturated fatty acids

Table 2. Content of selected macro- and micronutrients in the analysed species of nuts (own work based on [6])

\begin{tabular}{|c|c|c|c|c|c|c|c|c|}
\hline Species of nut & Ca [mg] & $\mathrm{Mg}[\mathrm{mg}]$ & $\mathrm{Na}$ [mg] & $\mathrm{K}[\mathrm{mg}]$ & Total tocopherol [mg] & $\mathrm{Fe}[\mathrm{mg}]$ & Zn [mg] & Se $[\mu \mathrm{g}]$ \\
\hline Macadamia & 85 & 130 & 5 & 368 & 0.54 & 3.7 & 1.3 & 3.6 \\
\hline Pecan & 70 & 121 & - & 410 & 26.7 & 2.5 & 4.5 & 3.8 \\
\hline Pine nut & 16 & 251 & 2 & 597 & 20.48 & 5.5 & 6.4 & 0.7 \\
\hline Brazil nut & 160 & 376 & 3 & 659 & 15.85 & 2.4 & 4.06 & 1917 \\
\hline Walnut & 98 & 158 & 2 & 441 & 23.57 & 2.9 & 3.09 & 4.9 \\
\hline Hazelnut & 114 & 163 & - & 680 & 15.36 & 4.7 & 2.4 & 2.4 \\
\hline Almond & 269 & 270 & 1 & 733 & 26.57 & 3.7 & 3.14 & 4.1 \\
\hline Pistachio & 105 & 121 & 1 & 1025 & 25.7 & 3.92 & 2.2 & 7 \\
\hline Cashew & 37 & 292 & 12 & 660 & 6.6 & 6.68 & 5.78 & 19.9 \\
\hline Groundnuts & 92 & 168 & 18 & 705 & 8.33 & 4.5 & 3.2 & 7.2 \\
\hline
\end{tabular}

All values are expressed per $100 \mathrm{~g}$ of dry product

$\mathrm{CA}$ - calcium; $\mathrm{Mg}$ - magnesium; $\mathrm{Na}$ - sodium; $\mathrm{K}$ - potassium; $\mathrm{Fe}$ - iron; $\mathrm{Zn}-$ zinc; Se - selenium

sideration only the tree-growing nuts, so-called "tree nuts", and excluded the groundnuts, which botanically are classified as grain legumes, and on account of their nutritional value are frequently included in the nut group in human nutrition science [7].

A detailed analysis of the energy and nutritional value including different types of nuts was shown in table 1. Table 2 draws a particular attention to properties beneficial for type 2 diabetes treatment. The aim of the study was to review the conducted research concerning the nut consumption effect on the value control of glycaemia, lipoprotein, blood pressure and the body weight as well as the importance of nuts being demonstrated in type 2 diabetes risk reduction.

\section{The glycaemic control and the tissue} insulin resistance enhancement

Role of hyperglycaemia in the pathogenesis of complications of type 2 diabetes mellitus

Chronic hyperglycaemia activates a number of metabolic pathways, in particular it affects the severe non-enzymatic protein glycation, i.e. spontaneous bonding of sugar molecules (e.g. glucose) to protein molecules (mostly haemoglobin, albumin and collagen), lipids and nucleotides [8-10]. Anti-glycation systems, such as proteasomes and lysosomes, are not efficient enough to prevent this reaction from occurring at an increased blood glucose level. This leads to a number of complications. Glycation of collagen 
changes its spatial structure, which makes it resistant to proteolysis and creates insoluble deposits that accumulate in the walls of blood vessels. This, in turn, results in its stiffening and increases the risk of hypertension and stroke [8]. Modification of the structure of endothelium - internal membrane is in danger of developing atherosclerosis and diabetic microangiopathy. Moreover, the correlation between an increased concentration of collagen glycation products and the development of diabetic retinopathy and nephropathy caused by an increased permeability of the membrane and prothrombotic action [8, 9] was found. The glycation of crystallin is associated with the development of cataract [8]. The reaction of glucose with lipids results in an increased permeability of the membrane and the disturbance of pro-oxidative/antioxidative balance within the cell, and in the case of the glycation of DNA it accelerates the development of mutations and interferes with the transcription $[8,10]$. Non-enzymatic glycation products, so-called AGEs (advanced glycation end-products) increase oxidative stress and result in the degradation of cell structures [10]. It has been shown that by binding to specific receptors - RAGEs (receptor for advanced glycation end-products), located on the surface of cells, they can impair their functioning by inducing the production of ROS (reactive oxygen species) and active transcription factors [8-10]. It is worth emphasizing that hyperglycaemia can also be the cause of acute complications which include diabetic ketoacidosis, hypoglycaemic and hyperglycaemic condition and lactic acidosis [4]. Considering the role of chronic hyperglycaemia and non-enzymatic glycation in the pathogenesis of complications of type 2 diabetes, the control of glucose level during treatment is crucial.

\section{Glycaemia control - current recommendations}

Pursuant to the recommendations of the ADA (American Diabetes Association) [11], fasting glycaemia in adult patients with type 2 diabetes should be maintained at the level of $80-130 \mathrm{mg} / \mathrm{dL}(4.4-7.2 \mathrm{mmol} / \mathrm{L})$, and at the moment of the so-called postprandial peak the capillary blood glucose level should not exceed $180 \mathrm{mg} / \mathrm{dL}$ (10.0 mmol/L). According to the IDF [12], the aim is to maintain the following values: glycated hemoglobin $\left(\mathrm{HbA}_{1 \mathrm{c}}\right)<7 \%(<53 \mathrm{mmol} / \mathrm{mol})$, glucose levels measured before a meal $-115 \mathrm{mg} / \mathrm{dL}(6.5$ $\mathrm{mmol} / \mathrm{L})$, and after a meal, $160 \mathrm{mg} / \mathrm{dL}(9.0 \mathrm{mmol} / \mathrm{L})$. In its recommendations from 2016, the Diabetes Poland [4] indicates the target value for $\mathrm{HbA}_{1 \mathrm{c}} \leq 7 \%$ ( $\leq 53$ $\mathrm{mmol} / \mathrm{mol}$ ) and draws attention to the fact that it is important to set the objective of the treatment on a case by case basis depending on the clinical situation, where other options such as $6.0,6.5$ and $8 \%$ are also possible. However, according to the latest guidelines, the recommended fasting glycemia value should be within the range of $80-110 \mathrm{mg} / \mathrm{dL}(4.4-6.1 \mathrm{mmol} / \mathrm{L})$, and $<140 \mathrm{mg} / \mathrm{dL}(7.8 \mathrm{mmol} / \mathrm{L})$ in the measurement carried out 2 hours after the start of the meal.

\section{Role of nuts in the postprandial glycaemia} control and an increase in insulin sensitivity

Kendall et al. [13] showed that nuts significantly reduce the postprandial glycaemia, which was confirmed by the meta-analysis carried out by Blanco Mejia et al. [14]. The test involved a small group of volunteers (10-14 healthy people and 5-10 people with type 2 diabetes) [13]. The aim of the test was to monitor the difference in the glucose level after the consumption of different portions of nuts $(30,60$ or $90 \mathrm{~g})$ or nuts added to wheat bread (containing $50 \mathrm{~g}$ of digestible carbohydrates). It was found that in each group the introduced portion of nuts was associated with a lower postprandial glycaemia value. In addition, eating them with wheat bread resulted in a lower increase in the glucose level in comparison to a meal consisting only a portion of bread. Moreover, a positive correlation between the amount of nuts added to a bread and the percentage of the postprandial glycaemia reduction (for $90 \mathrm{~g}$ of nuts the difference in the glucose level was almost 54\%). It was found that low carbohydrate content and significant fat and energy content result in the inhibition of gastric emptying, which affects the gradual absorption of glucose in the intestine and then a slow increase in its blood level. Blanco Mejia et al. [14] suggest that nuts decrease the glycaemic load of meals, which in turn results in the reduction of the postprandial glycaemia. This is due to the presence of unsaturated fatty acids, both MUFA (monounsaturated fatty acids) and PUFA (polyunsaturated fatty acids) in nuts. In another study, Kendall et al. checked the impact of pistachios on the postprandial glycaemia [15], which was administered in three portions: 28, 56 and $84 \mathrm{~g}$ as a separate meal or in combination with wheat bread. Then the blood glucose level was measured after 30, 45, 60 and 90 minutes after their consumption. It was found that the increase in the postprandial glycaemia was lower (below $5 \mathrm{mmol} / \mathrm{L}$ ) than after the consumption of a portion of wheat bread (approx. $7 \mathrm{mmol} / \mathrm{L}$ ), and the glucose level remained stable. A low carbohydrate content, including monosaccharides, and a high fat, protein and fibre content explain the occurrence of such an effect. In the test in which one meal consisted of a handful of pistachios and wheat bread (or another source of carbohydrates: pasta, rice, potatoes), a positive impact on the reduction of the glycaemic response was observed. Therefore, the 
authors suggest that it seems advisable to introduce pistachios to the diet as a factor reducing the risk of type 2 diabetes and as a tool modelling the glycaemic load of a given meal.

The literature also presents the results of the trials showing that nuts also have an influence on the improvement of the insulin sensitivity of tissues although the authors suggest that it may be largely caused by the simultaneous reduction of the body mass [16-19]. The PREDIMED trial [16], where nuts were an addition to the Mediterranean diet, showed the reduction of the postprandial glycaemia and insulin secretion and the improvement of insulin sensitivity measured using the HOMA-IR (Homeostatic Model Assessment Insulin Resistance) index. However, it should be pointed out that a similar effect was achieved in the group consuming olive oil [20]. The consumption of almonds ( $56 \mathrm{~g} / \mathrm{d}$ ) was also associated with the reduction of the HOMA-IR index in patients by $40 \%$ and the decrease in insulin secretion by $24-33 \%$ [17-19]. It is concluded that nuts can be a positive factor in the glycaemic control and in the improvement of the insulin sensitivity and the effect was the most frequently observed after 4-6 weeks.

\section{Role of nuts in the primary prevention of type 2 diabetes}

The NHS (Nurses Health Study, 83,818 women) showed that the consumption of nuts seems to be a protective factor in the aspect of the development of type 2 diabetes [21]. This effect was independent of variables such as: age, overweight or obesity, physical activity, family history, diet type and smoking. The PHS (Physicians Health Study, 20,224 men) confirmed this pattern [22]. People from the group consuming the highest amount of nuts ( $>7$ portions/week, portion - $28 \mathrm{~g}$ ) demonstrated a significantly lower risk of the occurrence of type 2 diabetes than subjects declaring a less frequent consumption. The PREDIMED trial (The Prevención con Diet Mediterránea, 418 patients) [23] provided evidence for the implementation of nuts (30 g) (or olive oil - $1 \mathrm{l} /$ week) to reduce the risk of the occurrence of type 2 diabetes (approx. 50\%).

It was shown that walnuts are particularly important in the primary prevention of type 2 diabetes due to the fact that they contain alpha-linolenic acid $(9.08 \mathrm{~g} / 100 \mathrm{~g})$, which increases insulin sensitivity [6, 24]. A more frequent consumption of nuts was associated with a clearly lower risk of the development of noninsulin dependent diabetes mellitus [24]. The likelihood of the occurrence of this disease in people declaring the consumption of at least 2 portions/week (portion - $28 \mathrm{~g}$ ) vs. 1 portion/week and 1-3 portions per month was much lower. In the randomized clinical trial, Tan and
Mattes [25] showed that in the group demonstrating an increased risk of the development of type 2 diabetes, the consumption of almonds in the amount of $43 \mathrm{~g} / \mathrm{d}$ had a positive impact on the postprandial glycaemia and increased the feeling of satiety. Apart from this, the consumption of nuts did not lead to the body weight gain in patients even though they have a high energy value. According to the researchers, this may be due to a high amount of fibre in the nuts which contributes to a lower digestibility of glucose by increasing the viscosity of the intestinal contents and has a positive impact on the regulation of the postprandial glycaemia $[6,26]$. Therefore, nuts can be used in the primary prevention of type 2 diabetes and the consumption of one portion, i.e. approx. $30 \mathrm{~g}$, have given the best results so far [22-24].

\section{The role of nuts in type 2 diabetes control and the complication prevention (secondary prevention)}

When analysing the significance of nuts in the secondary prevention of type 2 diabetes it is justified to demonstrate their impact on the specific treatment objectives proposed by Polish Diabetes Association [4].

\section{The impact of the nut consumption} on the glycaemic index

The evidence submitted above confirmed, that nuts reveal positive impact on the glycaemic index and the tissue resistance [13-19]. However, in the process of disease progress monitoring there is an additional index applied - $\mathrm{HbA}_{1 \mathrm{c}^{\prime}}$ which enables to reflect the glycaemic state up to three months back, which is linked to the period of the erythrocyte life cycle (8-12 weeks) [4, 27].

Jenkins et al. attempted to check if the replacement of a part of carbohydrates in the diet of type 2 diabetic patients with nuts were favourable, which would cause the increased percentage of the unsaturated fatty acids consumption [28]. The study was carried out on 117 volunteers. After 3 months significant reduction of $\mathrm{HbA}_{1 \mathrm{c}}$ in the group consuming $75 \mathrm{~g} / \mathrm{d}$ of nuts was observed (the diet contained $8.7 \%$ MUFA, and $45 \%$ of energy from carbohydrates). In addition to the glycaemia improvement the decrease in total cholesterol (TC), LDL-cholesterol (LDL-C), apoB concentration as well as the apoB/apoA ratio was found, which indicates the beneficial effects also of the lipid profile. The role of nuts in the reduction of $\mathrm{HbA}_{1 \mathrm{c}}$ concentration (on average by $7 \%$ ) was confirmed by the performed metaanalysis of the 12 randomized clinical research [29]. On the contrary, no correlation was found between their consumption and either the reduction in the insulin secretion nor the insulin resistance. The inclusion of 
nut portion into the diet often entailed the elimination of high-glycaemic-index carbohydrate snacks, which concurrently lowered the glycaemic load of meals and snacks. In order to observe the improvement in glycaemia there was an averaged recommended therapeutic dose (based on the analysed studies) accepted, which amounted to $56 \mathrm{~g} / \mathrm{d}$ of nuts (about half of a glass) consumed over a period of approximately 8 weeks.

\section{The significance of nuts in the}

\section{cardiovascular disease risk reduction}

It was shown that the risk of cardiovascular diseaserelated deaths in patients with type 2 diabetes was 2-fold for men and 3-4 times higher for women [3]. Additionally, the incidence of atherosclerosis was 2 times higher in patients with diabetes than in healthy ones. It is caused by the impact of the insulin resistance on endothelium dysfunction, development of the atherosclerotic plaque and the inflammation increase. In connection with the foregoing it is extremely important to monitor dyslipidemia, hypertension as well as overweight and obesity, as additional factors affecting the risk of CVD (cardiovascular diseases) in patients with type 2 diabetes [3, 4]. The contribution of nuts in the reduction of the cardiovascular disease risk was acknowledged by the two meta-analyses, which found that the consumption of them in the amount of on serving a week is related to the decrease in risk by $5 \%$ [30, 31]. On the other hand Zhou et al. [31] showed that the daily consumption of nuts enhances the effect up to $19 \%$. According to the FFQ analysis (Food Frequency Questionnaire) [32], conducted in years 1980-2002 in women with type 2 diabetes (6309 subjects), the consumption of at least 5 servings per week was associated with lower probability of developing CVD by $44 \%$ in comparison to the control group. The nut portion of $50-100 \mathrm{~g} / \mathrm{d}$ resulted in higher concentration of monounsaturated fatty acids in the blood, especially of oleic acid, which negatively correlated with other cardiovascular disease risk factors as well as with the 10-year CVD-induced risk of death. Alongside the consumption of $56 \mathrm{~g} / \mathrm{d}$ of walnuts the TC and LDL-C concentration reduction was observed [33]. Concurrently, due to the improvement of vasodilatation and blood circulation the betterment of the endothelial function was found. However, no changes in relation to the triglycerides level (TG), HDL-cholesterol (HDL-C) concentration as well as to blood pressure were noted.

In turn, examining the impact of the hazelnut oil on the lipid profile the concentration decrease of TC, LDL-C, VLDL-cholesterol (VLDL-C) and TG slight concentration increase of HDL-C were observed [34]. In another study, the replacement of $20 \%$ of energy in a diet with the portion of almonds ( $56 \mathrm{~g}$ ) also resulted in a better control of dyslipidemia [35]. A decline of TC concentration by $6 \%$, LDL-C by $11.6 \%$, and the LDL-C/ /HDL-C ratio decrease by $9.7 \%$ was recorded. The improvement in the after-meal glycaemia as well as the insulin concentration was observed.

The authors enumerate a number of nutrients present in nuts, which may favourably affect the lipid profile and the CVD risk reduction [36-39]. Above all, the attention should be drawn to a low content of saturated fatty acids (predisposing to arteriosclerosis), and a large content of unsaturated fatty acids (with MUFA predominance) showing protective properties. Walnuts compared with other species of nuts, are characterized by a greater percentage of alpha-linolenic acid, thus demonstrate anti-inflammatory (through the induction of prostaglandin synthesis) and antiaggregation properties [6]. The vasodilatatory action corresponds to the nut-present arginine, which is the precursor of nitrogen oxide [39], and the contained fibre results in glycaemia improvement, body weight and TC reduction [26]. Additionally, the nut-present vegetable protein, phytosterols and minerals may also play a favourable role in this respect [36-39]. Nuts also demonstrate antioxidant properties associated with the presence of tocopherol and selenium, which due to the reduction of free radicals generation may weaken the oxidation of strongly atherogenic LDL particles [36-40].

The impact of nuts on the body weight change

Owing to their high energy density (553-718 kcal) appear to predispose to the increased adipose tissue accumulation (FM, fat mass) and the body weight gain [6]. However, another dependency turned out to have been observed [41, 42]. No connection between the nut consumption (30-60 g/d for 12 weeks) and the body weight, including adipose tissue was noted [42]. The significant decrease in body weight, waist circumference and FM content [43] was observed in patients with metabolic syndrome whose previously recommended diet had been enriched with a portion of nuts $(30 \mathrm{~g} / \mathrm{d})$. The outcomes of The Adventist Health Study 2 [44] indicate that people with a higher consumption of these products (approximately $16 \mathrm{~g} / \mathrm{d}$ ) had a lower affinity for obesity (by about 37\%) when compared to the subjects whose average consumption did not exceed $5 \mathrm{~g} / \mathrm{d}$. Interestingly, the risk of being overweight decreased with each of the servings consumed, whilst an inverse relationship was observed with regard to groundnuts, which are not classified under "tree nuts" but under grain legumes [7, 44, 45]. The reduction of waist circumference serves to minimise the potential for abdominal obesity, which is strongly connected 
with the incidence of insulin resistance, and equally predisposes to a atherosclerosis and ischemic heart disease, therefore, it has an important contribution to the treatment of type 2 diabetes and metabolic syndrome (MS) $[3,4]$.

Jaceldo-Siegl et al. found that the consumption of one portion of nuts a week reduces the possibility of metabolic syndrome by $7 \%$, and of two portions even by $14 \%$ [44]. The effect remains independent of the lifestyle and demographic factors. In the meta-analysis covering 49 randomized clinical research regarding the impact of nuts on MS criteria, no significant reduction of waist circumference was observed, however, if they constituted the addition to the low-carbohydrate, the Mediterranean, the Dash and Portfolio diets, the meaningful body weight loss or the lack of the any change was reported [14].

The mice-performed study revealed that the macadamia oil supplementation is favourable for the existing obesity, since it affects the weakening of the inflammation induced by cytokines secreted by fat cells and reduces the growth of adipocytes [46]. A similar effect was achieved with pine nuts (the experiment carried out on obese rats), which, after being consumed for 12 weeks reduced the body weight by $17 \%$ alongside the white adipose tissue decrease by $18 \%$ (WAT, white adipose tissue), which is responsible for accumulation of triglycerides and cholesterol esters, release of free fatty acids and having the endocrine role $[47,48]$. On the other hand, almonds consumed with a low-carbohydrate diet revealed the synergistic effect, affecting the increased loss of body weight (by approximately 3.6\% higher in comparison with the control group within the period of 6 months), and they also caused the lipid profile betterment (decrease of TG, TC, LDL-C and VLDL-C) [49]. The importance of pistachios in the body weight reduction was in examined in the Hindu population, in which the higher tendency for abdominal obesity was stated [50]. The consumption of nuts in the amount of $20 \%$ of the diet energy affected the reduction of TC and LDL-C (due to a high content of MUFA) as well as the adiponectin increase. It was also revealed that their intake correlated, in the specified ethnic group, with the loss of body fat spread viscerally as well as with the oxidative stress reduction.

In recent years a number of hypotheses have emerged which aimed at explaining the lack of the expected body weight loss alongside the nut implementation. This may be caused by the incomplete energy absorption as well as the after-meal thermogenesis intensification, which corresponds to a higher protein intake and the lipid oxidation increase induced by the increased supply of unsaturated fatty acids [14, 51 , 52]. Another suggestion given was the one referring to the increased secretion of fat in faeces and obstructed digestion, related to the nut formation, enabling the destruction only of the first layer of cells $[43,53]$. In the groups consuming nuts, the faster postprandial satiety, persisting for several hours after the meal was observed [14, 53]. The components responsible for the mechanism are most likely fibre and protein. It must also be noted that the energy density of these products is equally important. It was found that chewing almonds reduces the sense of hunger 10-40 times and contributes to the postprandial fullness being felt up to 2 hours after a meal [54]. It is believed that the high energy density of nuts is compensated by the decrease of calories supply (55-75\% of energy), the loss of fat in feces (10-15\% of energy) and the increased energy use $(10 \%$ of energy), which accounts for no connection between their consumption and body weight gain being noted [52].

In view of above, nuts can be an effective factor in maintaining appropriate body weight and/or reduction of excessive body weight, although there is a need to conduct additional research in this area. However, on the basis of the existing literature [41-44, 47, 49], it can be concluded that they constitute a safe tool in both the glycaemic control and the lipid profile without the risk of adipose tissue gain, especially of the visceral one. There is a high probability of its reduction despite the high energy density demonstrated by nuts. The recommended intake of nuts in a daily diet without the risk of body weight gain amounts to 30-50 g/d [55].

\section{Nuts in the process of blood pressure regulation}

The insulin resistance stimulates the adipocytes to increase the production of angiotensin II, which is responsible for the vessel contraction as well as for the blood pressure increase. L-arginine by stimulating the production of nitric oxide (NO) of vasodilatatory properties, demonstrates the antagonistic behaviour [3]. The nut-present magnesium additionally intensifies the action of nitrogen oxide and prostacyclines, as well as blocks the calcium channels. Nuts simultaneously contain high ratio of potassium, the lack or a slight amount of sodium, a large amount of MUFA, PUFA, folate and other antioxidant ingredients, which may be involved in the blood pressure regulation [6].

Meta-analysis of the 4 prospective studies revealed a positive correlation between the consumption of nuts and the reduced risk of hypertension [31]. The analysis of the following 7 studies showed, that every next serving of nuts daily decreases the likelihood of 
coronary heart disease by $19 \%$ [19]. Yazdekhasti et al. [56], under the examination of this dependence in the Iranian population, showed their significant impact on the reduction of systolic and diastolic blood pressure, regardless of whether the nuts were roasted or salted. However, the PREDIMED examination [57] provided inconsistent results, which were justified by the authors with the probable lack of impact of the nuts on the secondary prevention - the majority of participants demonstrated hypertension. Positive results were obtained by applying the Mediterranean diet with the addition of 30-84 $\mathrm{g}$ of walnuts, almonds or their mixture or 20-50 $\mathrm{g}$ of walnuts exclusively [19]. However, it is worth noting, that the more frequent intake (at least once a day) was associated with the more seldom incidence of hypertension than in other groups [57]. Barbour et al. [19] in the review involving 44 studies concerning the effects of nuts on hypertension demonstrated that the treatment improvement occurs when it is accompanied by the long-term and regular consumption. The authors indicate that nuts constitute an important component of the diet designed for people suffering from hypertension, especially when other changes are being implemented.

\section{Summary}

Nuts constitute an essential ingredient of a diet even in patients with type 2 diabetes. Due to the documented action in terms of the glycaemic control, the lipid profile, the blood pressure, and weight control, the action should be implemented as a tool for the realisation of the assumed therapeutic objectives as well as the prevention of numerous disease complications, including type 2 diabetes. The lack of the risk related to the body weight gain resulting from the nut consumption, which are characterised by high energy density and fat content, should be stressed. This should orientate nutritionists and physicians on the wider use of these products in the development of dietary recommendations. With respect to the recommended intake of nuts the information is inconsistent (except for the FDA recommendations advising $42 \mathrm{~g} / \mathrm{d}$ of nuts in order to reduce the risk of CVD). It is believed that within the control of type 2 diabetes as well as the primary prevention, the minimum intake of nuts should be at least $30 \mathrm{~g} / \mathrm{d}$, accounting for the emerging reports on the validity and safety (bearing no risk of


glycaemic control) by stressing the regularity essence of their consumption and long-term support of the introduced changes.

\section{Conflict of interest}

The authors declare no conflict of interests.

\section{REFERENCES}

1. Global report on diabetes 2016. Geneva: World Health Organization; 2016. http://apps.who.int/iris/bitstream/10665/204871/1/ 19789241565257_eng.pdf (03 October 2016).

2. International Diabetes Federation. Diabetes Atlas - Seventh edition 2015 [online]. Brussels: International Diabetes Federation 2015. http://www.diabetesatlas.org/ (03 October 2016).

3. Langley-Evans S, Grzymisławski M. Żywienie. Wpływ na zdrowie człowieka. 1st ed. PZWL Jarosz M (ed), Warszawa 2013.

4. Polskie Towarzystwo Diabetologiczne. Zalecenia kliniczne dotyczące postępowania u chorych na cukrzycę 2016. Diabetologia Kliniczna. 2016; 5(supl. A): 1-A84.

5. Cichocka A. Cukrzyca typu 2. Cz. I. Epidemia naszych czasów. Przemysł Spożywczy 2013: 38-40.

6. USDA. Natio Nutrient Database for Standard Reference Release 28. https://ndb.nal.usda.gov/ndb/ (08 September 2016).

7. Bewley JD, Black M, Halmer P. The Encyklopedia of Seeds: Science, Technology and Uses. United Kingdom: CABI 2006. http:// //books.google.pl/books/about/The_Encyclopedia_of_Seeds. html?id=aE414KuXu4gC\&redir esc=y (04 October 2016).

8. Wierusz-Wysocka B, Araszkiewicz A, Schlaffke J. Końcowe produkty glikacji - nowy biomarker cukrzycy i jej powikłań? Diabetologia Kliniczna. 2013; 2: 96-103.

9. Brandt A, Zorena K, Myśliwiec M. Końcowe produkty glikacji —źródło pochodzenia a rozwój powikłań cukrzycowych. Diabetologia praktyczna. 2008; 9: 12-17.

10. Warwas M, Piwowar A, Kopiec G. Zaawansowane produkty glikacji (AGE) w organizmie - powstawanie, losy, interakcja z receptorami i jej następstwa. Farmakologia Polska. 2010; 66: 585-590.

11. American Diabetes Association. Standards of medical care in diabetes - 2016. Diabetes Care. 2016; 39(Suppl 1): 1-112.

12. International Diabetes Federation. Global Guideline for Type 2 Diabetes. Brussels: International Diabetes Federation 2012. https:// www.idf.org/sites/default/files/IDF\%20T2DM\%20Guideline.pdf (03 October 2016).

13. Kendall CWC, Esfahani A, Josse AR, et al. The glycemic effect of nut-enriched meals in healthy and diabetic subjects. Nutr Metab Cardiovasc Dis. 2011; 21 Suppl 1: S34-S39, doi: 10.1016/j.numecd.2011.03.013, indexed in Pubmed: 21561748.

14. Blanco Mejia S, Kendall CWC, Viguiliouk E, et al. Effect of tree nuts on metabolic syndrome criteria: a systematic review and meta-analysis of randomised controlled trials. BMJ Open. 2014; 4(7): e004660, doi: 10.1136/bmjopen-2013-004660, indexed in Pubmed: 25074070.

15. Kendall CWC, Josse AR, Esfahani A, et al. The impact of pistachio intake alone or in combination with high-carbohydrate foods on post-prandial glycemia. Eur J Clin Nutr. 2011; 65(6): 696-702, doi: 10.1038/ejcn.2011.12, indexed in Pubmed: 21364607.

16. Casas-Agustench P. Bullo M, Salas-Salvado J. Nuts, inflammation and insulin resistance. Asia Pac J Clin Nutr. 2010; 19: 124-130.

17. Wien $M$, Bleich $D$, Raghuwanshi $M$, et al. Almond consumption and cardiovascular risk factors in adults with prediabetes. J Am Coll Nutr. 2010; 29(3): 189-197, doi: 10.1080/07315724. 2010.10719833, indexed in Pubmed: 20833991.

18. Adamsson V, Reumark A, Fredriksson IB, et al. Effects of a healthy Nordic diet on cardiovascular risk factors in hypercholesterolaemic subjects: a randomized controlled trial (NORDIET). J Intern Med. 2011; 269(2): 150-159, doi: 10.1111/j.1365-2796.2010.02290.x, indexed in Pubmed: 20964740.

19. Barbour JA, Howe PR, Buckley JD, et al. Nut consumption for vascular health and cognitive function. Nutr Res Rev. 2014; 27(1): 131-158, doi: 10.1017/S0954422414000079, indexed in Pubmed: 24866624. 
20. Salas-Salvadó J, Bulló M, Babio N, et al. PREDIMED Study Investigators. Reduction in the incidence of type 2 diabetes with the Mediterranean diet: results of the PREDIMED-Reus nutrition intervention randomized trial. Diabetes Care. 2011; 34(1): 14-19, doi: 10.2337/dc10-1288, indexed in Pubmed: 20929998.

21. Jiang R. Nut and Peanut Butter Consumption and Risk of Type 2 Diabetes in Women. JAMA. 2002; 288(20): 2554, doi: 10.1001/ /jama.288.20.2554.

22. Kochar J, Gaziano JM, Djoussé L. Nut consumption and risk of type 2 diabetes in Physicians' Health Study. Eur J Clin Nutr. 2010; 64: 75-79.

23. Murie-Fernandez $M$, Irimia $P$, Toledo $E$, et al. PREDIMED Investigators. Carotid intima-media thickness changes with Mediterranean diet: a randomized trial (PREDIMED-Navarra). Atherosclerosis. 2011; 219(1): 158-162, doi: 10.1016/j.atherosclerosis.2011.06.050, indexed in Pubmed: 21802081.

24. Pan A, Sun Qi, Manson JE, et al. Walnut consumption is associated with lower risk of type 2 diabetes in women. J Nutr. 2013; 143(4): 512-518, doi: 10.3945/jn.112.172171, indexed in Pubmed: 23427333

25. Tan SY, Mattes RD. Appetitive, dietary and health effects of almonds consumed with meals or as snacks: a randomized, controlled trial. Eur J Clin Nutr. 2013; 67(11): 1205-1214, doi: 10.1038/ejcn.2013.184, indexed in Pubmed: 24084509.

26. Dodevska MS, Sobajic SS, Djordjevic PB, et al. Effects of total fibre or resistant starch-rich diets within lifestyle intervention in obese prediabetic adults. Eur J Nutr. 2016; 55(1): 127-137, doi: 10.1007/s00394-015-0831-3, indexed in Pubmed: 25588971.

27. Biskupski A, Waligórski S, Kowalik B, et al. Glycated hemoglobin $\mathrm{HbA} 1 \mathrm{c}$ - a new risk marker for the outcome of cardiac surgery? Kardiochir Torakochirurgia Pol. 2014; 11(1): 7-11, doi: 10.5114/ /kitp.2014.41922, indexed in Pubmed: 26336385.

28. Jenkins DJA, Kendall CWC, Banach MS, et al. Nuts as a replacement for carbohydrates in the diabetic diet. Diabetes Care. 2011; 34(8): 1706-1711, doi: 10.2337/dc11-0338, indexed in Pubmed: 21715526.

29. Viguiliouk E, Kendall CW, Blanco Mejia S, et al. Effect of tree nuts on glycemic control in diabetes: a systematic review and metaanalysis of randomized controlled dietary trials. PLoS One. 2014; 9(7): e103376, doi: 10.1371/journal.pone.0103376, indexed in Pubmed: 25076495

30. Ma L, Wang F, Guo W, et al. Nut consumption and the risk of coronary artery disease: a dose-response meta-analysis of 13 prospective studies. Thromb Res. 2014; 134(4): 790-794, doi: 10.1016/j.thromres.2014.06.017, indexed in Pubmed: 25047173.

31. Zhou D, Yu H, He F, et al. Nut consumption in relation to cardiovascular disease risk and type 2 diabetes: a systematic review and meta-analysis of prospective studies. Am J Clin Nutr. 2014; 100(1): 270-277, doi: 10.3945/ajcn.113.079152, indexed in Pubmed: 24808491

32. Li TY, Brennan AM, Wedick NM, et al. Regular consumption of nuts is associated with a lower risk of cardiovascular disease in women with type 2 diabetes. J Nutr. 2009; 139(7): 1333-1338, doi: 10.3945/jn.108.103622, indexed in Pubmed: 19420347.

33. Ma Y, Njike VY, Millet J, et al. Effects of walnut consumption on endothelial function in type 2 diabetic subjects: a randomized controlled crossover trial. Diabetes Care. 2010; 33(2): 227-232, doi: 10.2337/dc09-1156, indexed in Pubmed: 19880586.

34. Al-Amoudi NS, Abu Araki HA. Evaluation of vegetable and fish oils diets for the amelioration of diabetes side effects. J Diabetes Metab Disord. 2013; 12(1): 13, doi: 10.1186/2251-6581-12-13, indexed in Pubmed: 23497544.

35. Li SC, Liu YH, Liu JF, et al. Almond consumption improved glycemic control and lipid profiles in patients with type 2 diabetes mellitus. Metabolism. 2011; 60(4): 474-479, doi: 10.1016/j. metabol.2010.04.009, indexed in Pubmed: 20580779.

36. Sabaté J, Wien M. Consumption of Nuts in the Prevention of Cardiovascular Disease. Current Nutrition Reports. 2013; 2(4): 258-266, doi: 10.1007/s13668-013-0059-x.

37. Kris-Etherton PM, Hu FB, Ros $E$, et al. The role of tree nuts and peanuts in the prevention of coronary heart disease: multiple potential mechanisms. J Nutr. 2008; 138(9): 1746S-1751S, indexed in Pubmed: 18716180.

38. Griel AE, Kris-Etherton PM. Tree nuts and the lipid profile: a review of clinical studies. Br J Nutr. 2006; 96 Suppl 2: S68-S78, indexed in Pubmed: 17125536.
39. Sabaté J, Oda K, Ros E. Nut consumption and blood lipid levels: a pooled analysis of 25 intervention trials. Arch Intern Med. 2010; 170(9): 821-827, doi: 10.1001/archinternmed.2010.79, indexed in Pubmed: 20458092.

40. Alexiadou K, Katsilambros N. Nuts: anti-atherogenic food? Eur J Intern Med. 2011; 22(2): 141-146, doi: 10.1016/j.ejim.2010. 11.008, indexed in Pubmed: 21402243.

41. Flores-Mateo G, Rojas-Rueda D, Basora J, et al. Nut intake and adiposity: meta-analysis of clinical trials. Am J Clin Nutr. 2013; 97(6): 1346-1355, doi: 10.3945/ajcn.111.031484, indexed in Pubmed: 23595878.

42. Tey SL, Gray AR, Chisholm AW, et al. The dose of hazelnuts influences acceptance and diet quality but not inflammatory markers and body composition in overweight and obese individuals. J Nutr. 2013; 143(8): 1254-1262, doi: 10.3945/jn.113.174714, indexed in Pubmed: 23761651.

43. Casas-Agustench $P$, López-Uriarte $P$, Bulló $M$, et al. Effects of one serving of mixed nuts on serum lipids, insulin resistance and inflammatory markers in patients with the metabolic syndrome. Nutr Metab Cardiovasc Dis. 2011; 21(2): 126-135, doi: 10.1016/j. numecd.2009.08.005, indexed in Pubmed: 20031380.

44. Jaceldo-Siegl K, Haddad E, Oda K, et al. Tree nuts are inversely associated with metabolic syndrome and obesity: the Adventist health study-2. PLoS One. 2014; 9(1): e85133, doi: 10.1371/ /journal.pone.0085133, indexed in Pubmed: 24416351.

45. Cesarettin A, Fereidoon S. Tree Nuts: Composition, Phytochemicals, and Health Effects: An Overview. In: Cesarettin A, Fereidoon S (ed.). Tree Nuts: composition, phytochemicals, and health effects. Boca Raton: CRC Press Taylor \& Francis Group 2009.

46. Lima EA, Silveira LS, Masi LN, et al. Macadamia oil supplementation attenuates inflammation and adipocyte hypertrophy in obese mice. Mediators Inflamm. 2014; 2014: 870634, doi: 10.1155/2014/870634, indexed in Pubmed: 25332517.

47. Park S, Lim Y, Shin S, et al. Impact of Korean pine nut oil on weight gain and immune responses in high-fat diet-induced obese mice. Nutr Res Pract. 2013; 7(5): 352-358, doi: 10.4162/ /nrp.2013.7.5.352, indexed in Pubmed: 24133613.

48. Tatoń J, Czech A, Bernas M. Histofizjologiczna charakterystyka tkanki tłuszczowej: rozrost i przerost tkanki tłuszczowej w otyłości. In: Tatoń J, Czech A, Bernas M. ed. Otyłość. Zespół metaboliczny. Warszawa 2006: PZWL.

49. Foster GD, Shantz KL, Vander Veur SS, et al. A randomized trial of the effects of an almond-enriched, hypocaloric diet in the treatment of obesity. Am J Clin Nutr. 2012; 96(2): 249-254, doi: 10.3945/ajcn.112.037895, indexed in Pubmed: 22743313.

50. Gulati S, Misra A, Pandey RM, et al. Effects of pistachio nuts on body composition, metabolic, inflammatory and oxidative stress parameters in Asian Indians with metabolic syndrome: a 24-wk, randomized control trial. Nutrition. 2014; 30(2): 192-197, doi: 10.1016/j.nut.2013.08.005, indexed in Pubmed: 24377454.

51. St-Onge MP. Dietary fats, teas, dairy, and nuts: potential functional foods for weight control? Am J Clin Nutr. 2005; 81(1): 7-15, indexed in Pubmed: 15640454.

52. Mattes RD, Kris-Etherton PM, Foster GD. Impact of peanuts and tree nuts on body weight and healthy weight loss in adults. J Nutr. 2008; 138(9): 1741S-1745S, indexed in Pubmed: 18716179.

53. Rajaram S, Sabaté J. Nuts, body weight and insulin resistance. $\mathrm{Br}$ J Nutr. 2006; 96 Suppl 2: S79-S86, doi: 10.1017/bjn20061867, indexed in Pubmed: 17125537.

54. Cassady BA, Hollis JH, Fulford AD, et al. Mastication of almonds: effects of lipid bioaccessibility, appetite, and hormone response. Am J Clin Nutr. 2009; 89(3): 794-800, doi: 10.3945/ /ajcn.2008.26669, indexed in Pubmed: 19144727.

55. Vadivel V, Kunyanga CN, Biesalski HK. Health benefits of nut consumption with special reference to body weight control. Nutrition. 2012 Nov-Dec; 28(11-12): 1089-1097.

56. Yazdekhasti N, Mohammadifard N, Sarrafzadegan N, Mozaffarian D, Nazem M, Taheri M. The relationship between nut consumption and blood pressure in an Iranian adult population: Isfahan Healthy Heart Program. Nutr Metab Cardiovasc Dis. 2013 Oct; 23(10): 929-936.

57. Ibarrola-Jurado N, Bulló M, Guasch-Ferré M, et al. Cross-Sectional Assessment of Nut Consumption and Obesity, Metabolic Syndrome and Other Cardiometabolic Risk Factors: The PREDIMED Study. PLoS ONE. 2013; 8(2): e57367, doi: 10.1371/journal. pone.0057367. 